\title{
Engrave on the Heart and Wash Away Care
}

\begin{abstract}
The Diamond Sütra of the second half of the sixth century on Mount Tai ranks among the most powerful monuments of China. On an area of some 2,000 square meters are engraved more than 2,500 characters of the sacred text; and on the boulders and rock escarpment bordering the sūtra, more than 60 colophons were added over the centuries, allowing us to trace the history of the site in great detail. Two of these colophons by the same calligrapher - a poem and an epigraph dated 1603 - are the subject of this paper.
\end{abstract}

\section{Introduction}

The Diamond Sūtra on Mount Tai (Fig. 1) is one of the great monuments of China, and, indeed, the world. On an area of some two thousand square meters, 2,747 characters were engraved, of which 1,468 are still extant. Many of them are more than $50 \mathrm{~cm}$ high. In 45 columns they come cascading down over the rocky expanse. More than 60 colophons surround the sūtra. These individual manuscripts, engraved over the centuries, allow us to trace how the sūtra was judged and appreciated throughout history. Many of these colophons are intricate, full of biographical and historical detail. Their texts and their calligraphy are often quite beautiful, but not always easy to decipher. Two of them, an epigraph dated 1603 and the other a poem, overwritten by a third inscription, are the subject of this paper.

\section{The epigraph}

The epigraph is engraved on the flat top of a boulder that is hidden among the trees in the upper left (i.e., the north-western) corner of the sūtra field (Fig. 2). The inscription, in fine lines, is written in regular script that tends towards running script (xingkai shu 行楷書). The four main characters read:

\section{銘心淘虑}

Engrave on the Heart and Wash Away Care 
There is no locus classicus for this phrase, but it is replete with both, Buddhist and Neo-Confucian notions.

About a century before the epigraph was written in Sūtra Stone Valley, the concept 'heart' or 'mind' (xin 心) had figured prominently in the thinking of the Ming Confucian philosopher Wang Yangming 王陽明 (1472-1529). He held that 'heart' and 'reason' (li 理) are not separate, and that the world is grounded in the heart. Here he concurred with long-held Buddhist convictions. The sixth patriarch of the Chan School, Huineng 慧能 (638-713), was enlightened when listening to a lecture on the Diamond Sütra, whereupon he coined a saying that was transmitted through his disciple, Nanyue Huairang 南狺懷讓 (677-744): 'All dharmas rise from the heart'一切法皆從心生.'

The author of the epigraph may also have thought more generally of the 'sincere heart' (zhen xin 真心), which is the necessary requirement for sentient beings to attain Buddhahood; or he may have been thinking of the 'mind/heart of mental appropriation of cognitive objects' (yuanlü xin 緣慮心).

The two-character phrase ming xin 銘心 ('engrave on the heart') was also used by Buddhists and Confucian thinkers alike. When the renowned Tang dynasty exegete Chengguan 澄觀 (738-839) explained the term in his Autocommentary to the Exegesis of the Buddhāvatamsaka Sūtra (Dafangguang Fo Huayanjing suishu yanyi chao 大方廣佛華嚴經隨疏演義鈔), he emphasized the permanence of an engraving:

言銘心者, 猶如刻銘, 長記不滅. ${ }^{2}$

'Words engraved on the heart' are like a carved engraving that will be on record for a long time and will not vanish.

The eminent Neo-Confucian philosopher Zhu Xi 朱喜 (1130-1200) gave the word ming 銘 ('engrave') a moral dimension in his commentary to the Confucian classical text The Great Learning (Daxue 大學), which comprises a quote of an inscription on a bronze basin of antiquity inscribed by the alleged first Shang ruler Tang 湯:

\section{湯之《盤銘》：‘苟日新, 日日新, 又日新”. 3}

The engraving in Tang's basin reads: 'Sincerely renew yourself daily, ever newer from day to day, and new again with each passing day.'

1 CBETA, X25, no. 471, p. 14, b16-19 // Z 1:39, p. 14, b13-16 // R39, p. 27, b13-16.

2 Takakusu and Watanabe (eds) (1922-1932), no. 1736, vol. 36: $256 a 21$.

3 Ruan Yuan 2003, 1673b. Translation of the inscription in Plaks 2003, 7 (modified). 
We know today that there never was a bronze basin inscribed by a ruler Tang; but what interests us here is Zhu Xi's explanation of the sentence:

銘, 銘其器以自戒之辭也。苟, 誠也。湯以為人之洗滌其心以去惡, 如沐浴其身以去垢, 故銘其盤. ${ }^{4}$

On the word 'engraving': He engraved his vessel with words of self-admonition. Gou 荷 is to be read as cheng 誠, sincerely. Tang believed that a person could rid himself of evil by purifying his mind, just as he could bathe his body to rid himself of a stain. Therefor he engraved his basin.

Just as ruler Tang of yore kept himself vigilant by looking daily at an uplifting inscription in his basin, the writer of the epigraph in Sütra Stone Valley may have felt a purifying force exuding from the Diamond Sūtra, the most conspicuous engraving in sight.

The phrase 'engrave on the heart' in the epigraph of 1603 is thus a fine example of the doctrinal interaction between Confucianism and Buddhism in the late Ming period. ${ }^{5}$

For the second half of the epigraph, 'wash away care' (tao lü 淘慮), no classical source can be found. But there are similar phrases. Su Shi 蘇軾 (1037-1101) once wrote:

天下皆洗心滌濾, 以聽朝廷之所為. ${ }^{6}$

All the people in the realm should wash their hearts and cleanse them, in order to submit to the actions of the court.

A century later, Ye Shi 葉適 (1150-1223) said:

方齊心滌慮, 以俟陛下反復詰難, 庶幾竭盡愚衷.7

Today I purified my heart and cleansed myself of care, to prepare for repeated interrogation from Your Majesty, hoping my abject self can show that my dedication is limitless.

Both writers describe the mind and attitude of the dedicated and attentive official.

4 Okada 1977, I: 218a.

5 For this issue see e.g. Fang Litian 2000, 6.

$6 \mathrm{Wu}$ Yongzhe and Qiao Wanmin 2006, 143.

7 Zhuang Zhongfang 1998, 304. 
Obviously, ridding oneself of care was a continual concern for officials. In the biography of Nalan Mingzhu 納蘭明珠 (1635-1708), whom the Kangxi Emperor esteemed highly, one reads:

\section{原期得人, 亦欲令被舉者警心滌慮. ${ }^{8}$}

Originally in recruiting men, the expectation was that those who were recommended would keep their minds alerted and cleanse themselves of care.

These passages show that the epigraph in its entirety, 'engrave on the heart and wash away care', could refer specifically to those who wanted to embark on a career in the civil service.

For a long time it was not known who the writer of this epigraph was. The date in front of the four large characters was easy to read: 'On an auspicious day of the first month of winter [i.e., the tenth month] of the guimao year [1603]' 卯孟冬之吉. But the signature posed a problem (Fig. 3). Epigraphers had read it as 佛子無含/舍守訓 ('Disciple of the Buddha, Wuhan/Wushe Shouxun'). Yet no disciple of the Buddha with the names Wuhan or Wushe could be found.

\section{The poem}

The solution came in 2015, the year our research group embarked on a thorough study of all the colophons engraved in Sūtra Stone Valley. Eight were written, between 1572 and 1930, on the horizontal rock band north of the sūtra field (Fig. 4). In the middle is a colophon dated 1625 and signed by a metropolitan graduate of 1616 named Shuai Zhong 帥眾. It is principally composed of four large characters that read:

\section{枕流漱石 ${ }^{9}$}

Pillowing on the Stream and Rinsing with Rocks

Shuai Zhong overwrote and largely destroyed an inscription in small characters that were part of an earlier engraving. A rubbing of the rock surface (Fig. 5)

\footnotetext{
8 Zhao Erxun et al. 1976, 269: 9994.

9 Celia Carrington Riely has pointed out that Dong Qichang 董其昌 (1555-1636) once used the proper form of this deliberately unsettling expression as a frontispiece for a painting by one of his friends. See Ledderose (ed.), forthcoming.
} 
revealed some of the damaged characters in this palimpsest (Fig. 6). The earlier engraving turned out to be a poem of regulated verse (lüshi 律詩) of eight lines with seven characters each. The following can be read (numbers indicate the columns on the rock):

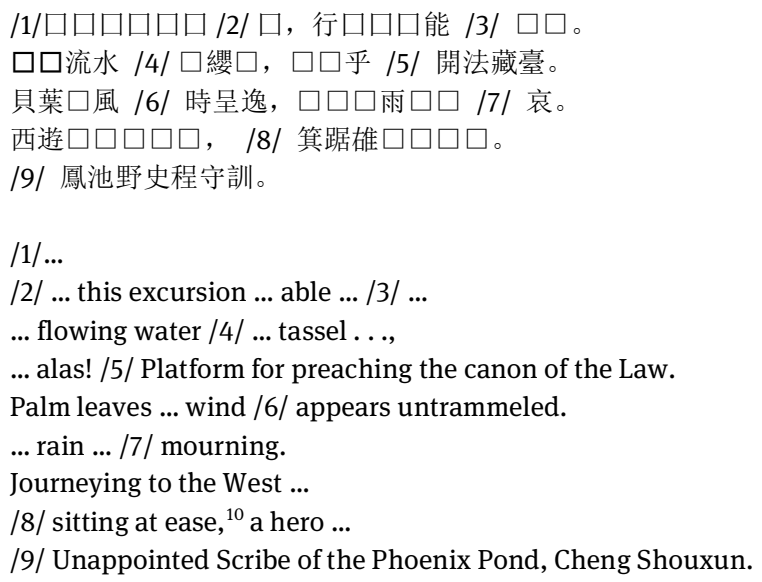

From the vantage point of the colophon northwest of the sūtra field, the entire Diamond Sütra can be seen at a glance, and this is what the author obviously had in mind. 'Platform for the canon of the Law' (fazang tai 法藏臺) is Sūtra Stone Valley; 'palm leaves' (beiye 貝葉) refers to the sūtra text; and 'opening the canon of the Law' (kai fazang 開法藏) means the propagation of Buddhist teaching. In addition, the character pair xiyou 西遊 may refer to the story of how Monk Xuanzang 玄弉 (c. 602-664) dried his soaked sūtras on the flat surface of a cliff, as recounted in the famous novel Journey to the West (Xiyou ji 西遊記). Another epigraph, Sūtra-Sunning Rock (pujing shi 暴經石) of 1572, alludes to this story and likens Sūtra Stone Valley to Xuanzang's cliff. The earliest printed version of the Journey to the West dates from 1592, only a few years before the poem was engraved. ${ }^{11}$

The signature of the poem reads: 'Unappointed Scribe of the Phoenix Pond, Cheng Shouxun’ 鳳池野史程守訓. The last character is not clear. Yet we know there existed a personage with the family name Cheng 程 whose personal name begins with the character shou 守. It was the eunuch Cheng Shouxun 程守訓

10 The term jiju 箕踞 ('sitting on the floor with legs outstretched') refers to a hermit's unrestrained way of life.

11 Zhou Ying 2010, 332-344. 
(died 1606), and, indeed, looking at the signature with this in mind, it appears that the last character is almost certainly xun 訓 (Fig. 6).

\section{The writer}

Cheng Shouxun was married to the niece 姪婿 of the notorious eunuch Chen Zeng 陳增 (died 1604), who procured for him a sinecure as 'Specially Appointed Drafter of the Central Drafting Office, assigned to the Hall of Military Glory’ 特授 中書舍人, 直武英殿. The Hall of Military Glory in the Forbidden City, where the Central Drafting Office was located, had a garden with a pond named the Phoenix Pond. When using Phoenix Pond in his signature to his poem, Cheng Shouxun was thus poetically referring to the prestigious Central Drafting Office, with which he was connected. Because he was not a regular scribe, he calls himself 'unappointed scribe'.

A similar signature is seen on the Tomb Stele for the Master of Alchemy Zan Yunshan (Zan Yunshan lianshi beiji 备雲山煉師碑記) of 1602 in the Daoist temple Sanyang Guan 三陽觀 on Mount Tai: 'Composed by the Drafter of the Central Drafting Office in the Hall of Military Glory, Disciple of the Buddha, Wunian Shouxun' 武英殿中書舍人佛弟子無念程守訓撰. Figure 7 shows the second half of the signature, where the name 'Cheng Shouxun' is clearly readable. He calls himself Disciple of the Buddha 佛弟子, and uses the sobriquet Wunian 無念 ('Without Thought'), a term with Buddhist overtones. The writer of the epigraph in Sūtra Stone Valley also calls himself 'Disciple of the Buddha' 佛子, and his sobriquet begins with the character $w u$ 無. If both were signatures of the same man, as we believe they are, then the character following $w u$ 無 in the signature of the epigraph should not be read han 含 nor she 舍, but nian 念, albeit in an unusual orthography (Fig. 3).

The conclusion that both inscriptions were written by the same hand is supported by the stylistic similarity in the thin lines of the calligraphy. Cheng Shouxun was respected as a calligrapher. In 1603 he wrote the main text on a stele in Huizhou 徽州 (now preserved in Lianyungang City 連雲港市) which praises Chen Zeng for having constructed a Buddhist monastery. ${ }^{12}$

12 Wang Meiding and Tang Zhongmian 1811, 494a. 


\section{Politics}

Cheng Shouxun's two inscriptions in Sūtra Stone Valley also invite a glimpse into the convoluted and acrimonious politics of the time. Chen Zeng was one of a large number of tax eunuchs 稅諨 whom the Wanli Emperor dispatched in 1596 to levy mining taxes. Chen was sent to Shandong, where he nominated Cheng Shouxun as his local delegate and made him Superintendent of Mining Tax 總理山東礦稅. ${ }^{3}$

Although Cheng Shouxun calls himself a disciple of the Buddha, and although - almost ironically - his name Shouxun 守訓 means 'abiding by the rules', the History of the Ming Dynasty (Mingshi 明史) portrays him as brutal and utterly arrogant. When extorting money, 'he encouraged people to give secret information against others, and had even women and children flogged and tortured' 許人告密, 刑拷及婦孺, ${ }^{14}$ and 'nobody dared to ask how many people he killed' 殺人莫敢問. ${ }^{15}$ Several powerful officials, including the Grand Secretary Shen Yiguan 沈一貫 (1531-1617), memorialised the emperor accusing Cheng Shouxun, but each time Cheng evaded punishment because Chen Zeng protected him.

The official who most vehemently opposed the eunuchs, and Chen Zeng in particular, was Li Sancai 李三才 (1554-1623). He presented a number of memorials to the throne that received no response, but nevertheless managed to have several members of Chen's clique executed. ${ }^{16}$ Chen Zeng, seeing the danger, betrayed Cheng Shouxun, revealing the wealth which Cheng had amassed. Thereupon the Emperor ordered Li Sancai to arrest Cheng and bring him to Beijing. In 1606 Cheng was tried and executed, ${ }^{17}$ causing 'great happiness far and wide' 遠近大快. ${ }^{18}$ Chen Zeng had already met a bitter end two years earlier: when he heard that soldiers had been sent to arrest him, he hanged himself. ${ }^{19}$

13 Zhao Lianwen 1991; Tsai 1996, 180; Fang Xing 2013, 128-130.

14 Zhang Tingyu 1974, 223: 6064.

15 Zhang Tingyu 1974, 305: 7806.

16 Zhang Tingyu 1974, 223: 6062; Goodrich and Fang 1976, 848; Fang Xing 2013, 130. In 1588 Li Sancai engraved a stele with a poem in Sūtra Stone Valley.

17 Zhao Jishi and Ding Tingjian 1975, 1:34b.

18 Zhang Tingyu 1974, 223: 6064.

19 Shen Defu 1997, 6:176. Zhang Tingyu 1974, 305: 7806 gives 1605 as the year of his death. But according to the Ming Shenzong shilu (Huang Zhangjian 1984, 403: 12089a) and Goodrich and Fang 1976, 848, he died in 1604. 
Shuai Zhong, who two decades later overwrote Cheng Shouxun's poem, is portrayed in the sources as another upright official. He was a censor and a sworn enemy of all eunuchs, and is said to have been

\section{清惠自持, 以治行擢. $\cdots$ 屢屢上疏諫言, 針砭時弊, 彈劾宦臣汗吏. ${ }^{20}$}

incorrupt and benevolent, as well as self-restrained, and, being good at governing, was promoted [...]. Time and again he memorialized the emperor remonstrating about the ills of the day, impeaching eunuchs at court and corrupt officials.

According to the History of the Ming Dynasty,

\section{禦史帥眾指斥宮禁, 閹人請帝出之外. 以向高救免. ${ }^{21}$}

the censor Shuai Zhong denounced the [situation in the] palace, whereupon the eunuchs begged the emperor to oust him. But being protected by [the Grand Secretary Ye] Xianggao 葉向高 [1559-1627], he was saved from dismissal.

When censor Shuai Zhong destroyed Cheng Shouxun's poem in Sūtra Stone Valley, he meted out punishment with his own hand.

\section{Acknowledgements}

The findings presented here are a tidbit in a long-term research project at the Heidelberger Akademie der Wissenschaften, whose support is gratefully acknowledged. A special thanks goes to Xia Momei 夏墨涺, who wrote a first substantial draft of this paper, and to Celia Carrington Riely 李慧聞, who unearthed Chinese sources and untiringly advised us on our English. At a critical juncture Michael Friedrich, to whom this volume is dedicated, kindly and successfully put in a good word for our project.

\section{References}

CBETA - Chinese Buddhist Electronic Text Association (Zhonghua dianzi fodian xiehui 中華電 子佛典協會), 1998-, Taibei.

Fang Litian 方立天 (2000), 'Ru, fo yi xinxinglun wei zhongxin de hudong hubu’ 儒、佛以心性論 為中心的互動互補, Zhongguo zhexueshi 中國哲學史, 2: 3-13.

20 Lü Maoxian 2006, 8: 23a-b.

21 Zhang Tingyu 1974, 240: 6237. 
Fang Xing 方興 (2013), 'Mingdai kuangjian shuishi shijian zhong de yuanzouguan (min)、 weiguan ji cansui' 明代礦監稅使事件中的原奏官（民）、委官及參隨, Zhongzhou xuekan 中州學刊, 9: 126-131.

Goodrich, L. Carrington and Chaoying Fang (eds) (1976), Dictionary of Ming Biography, 13681644, New York: Columbia University Press.

Huang Zhangjian 黄彰健 (ed.) (1984), Ming Shenzong shilu 明神宗實録, in Ming shilu. Fu jiaokanji 明實録（附校勘記), vols 11-13, Kyōto: Chūbun shuppansha.

Ledderose, Lothar (ed.), forthcoming, Buddhist Stone Sūtras in China, Shandong Province, vol. 4, Wiesbaden: Harrassowitz / Hangzhou: China Academy of Art Press.

Lü Maoxian 呂森先 (ed.) (2006), (Tongzhi) Fengxin xianzhi [同治] 奉新縣志 (Beijing Airusheng shuzihua jishu zhongxin 北京愛如生數字化技術研究中心 (ed.), Zhongguo fangzhi ku 中國 方志庫), reprint of the 1871 edition.

Okada Takehiko 岡田武彥 (ed.) (1977), Kai'an sensei Shu Bunkō bunshū / Huian xiansheng Zhu Wengong wenji 晦庵先生朱文公文集, 2 vols, reprint of the 1562 edn, Kyoto: Chūbun shuppansha.

Plaks, Andrew H. (tr.) (2003), Ta Hsüeh and Chung Yung (The Highest Order of Cultivation and On the Practice of the Mean), London: Penguin Books.

Ruan Yuan 阮元 (ed.) (2003), Shisan jing zhushu: fu jiaokan ji 十三經註疏：附校勘記, 2 vols, Beijing: Zhonghua shuju.

Shen Defu 沈德符 (1997), Wanli yehuo bian 萬曆野獲編 (Lidai shiliao biji congkan: Yuan Ming shiliao biji), 3 vols, Beijing: Zhonghua shuju.

Takakusu Junjirō 高楠 順次郎 and Watanabe Kaigyoku 渡邊海旭 (eds) (1922-1934), Taishō shinshū daizōkyō 大正新脩大蔵経, 85 vols, Tokyo: Taishō issaikyō kankōkai.

Tsai, Shih-shan Henry (1996), The Eunuchs of the Ming Dynasty, New York: SUNY Press.

Wang Meiding 汪梅鼎 and Tang Zhongmian 唐仲冕 (eds) (1811), (Jiaqing) Haizhou Zhili zhou zhi (嘉慶) 海州直隸州誌, in Huang Chengzhu 黃成助 (ed.), Zhonggou fangzhi congshu 中國 方志叢書, reprint of the 1811 edition, Taibei: Chengwen chubanshe, 1966-1989.

Wu Yongzhe 吳永喆 and Qiao Wanmin 喬萬民 (eds) (2006), Tang Song Ba dajia: Su Shi 唐宋 八大家：蘇軾, Tianjin: Tianjin guji chubanshe.

Zhang Tingyu 張廷玉 (ed.) (1974), Mingshi 明史, 28 vols, Beijing: Zhonghua shuju.

Zhao Erxun 趙爾巽 et al. (1976), Qingshi gao 清史稿, 48 vols, Beijing: Zhonghua shuju.

Zhao Jishi 趙吉士 and Ding Tingjian 丁廷楗 (eds) (1975), (Kangxi) Huizhou fuzhi (康熙) 徽州 府志 (Zhongguo fangzhi congshu: Huazhong difang 中國方志叢書：華中地方 237), reprint of the 1699 edn, 7 vols, Taibei: Chengwen chubanshe.

Zhao Lianwen 趙連穩 (1991), 'Ming Wanli nianjian kuangshuijian luanlu shulue’ 明萬曆年間礦 稅監亂魯述略, Qilu xuekan 齊魯學刊 4: 102-106.

Zhou Ying 周虽 (2010), Tai Shan yu zhonghua wenhua 泰山與中華文化, Jinan: Shandong youyi chubanshe.

Zhuang Zhongfang 莊仲方 (ed.) (1998), Nan Song wenfan 南宋文範, Changchun: Jilin renmin chubanshe. 


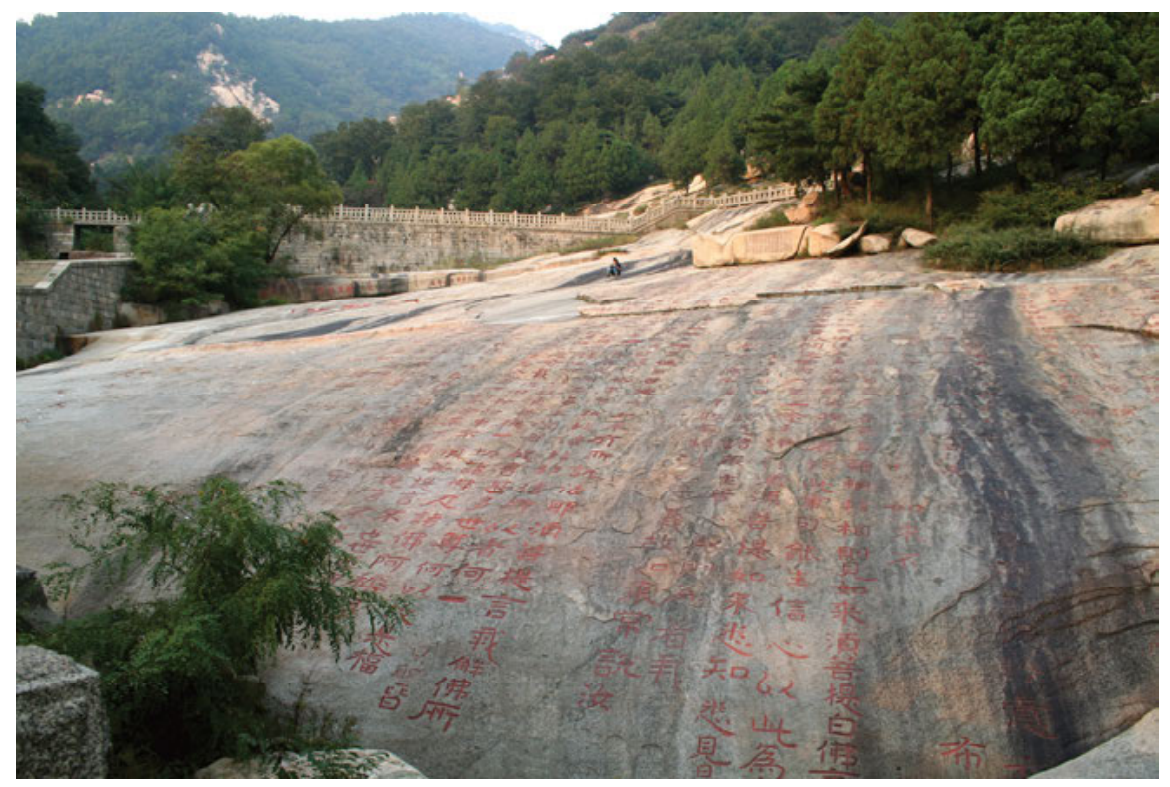

Fig. 1: The Diamond Sūtra, Sūtra Stone Valley on Mount Tai, Shandong, China, second half of the sixth century. (C) Heidelberger Akademie der Wissenschaften.

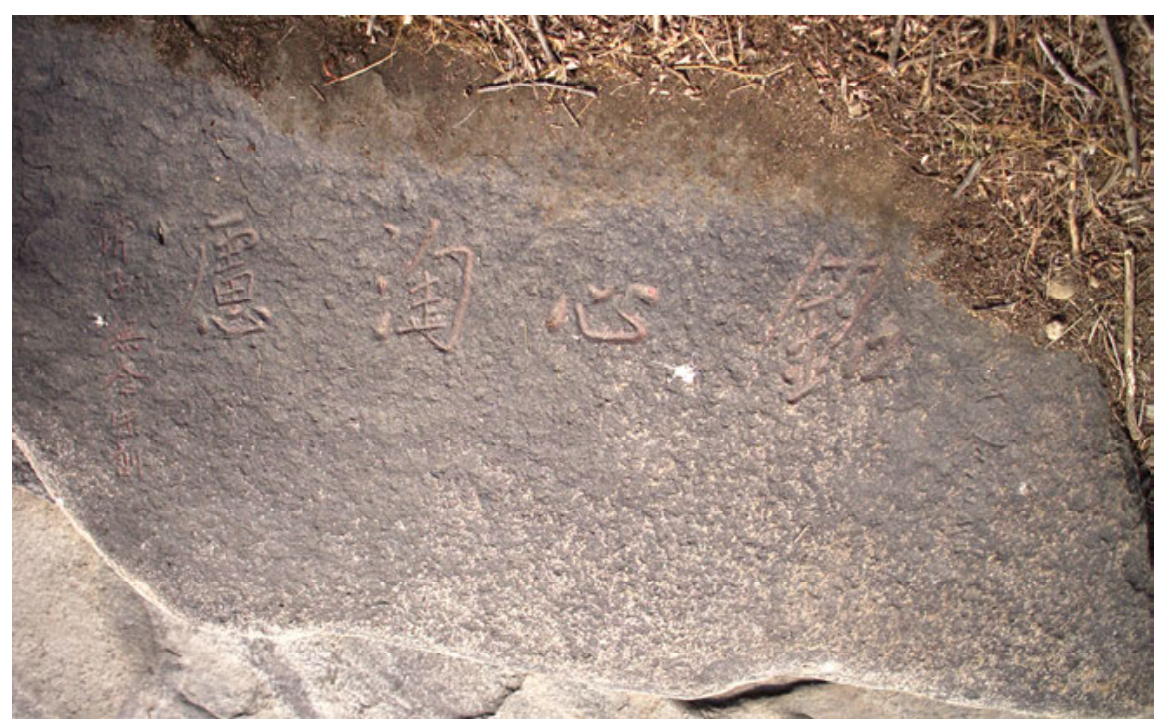

Fig. 2: 'Engrave on the Heart and Wash away Care', Epigraph, Sūtra Stone Valley on Mount Tai, 1603. (C) Heidelberger Akademie der Wissenschaften. 


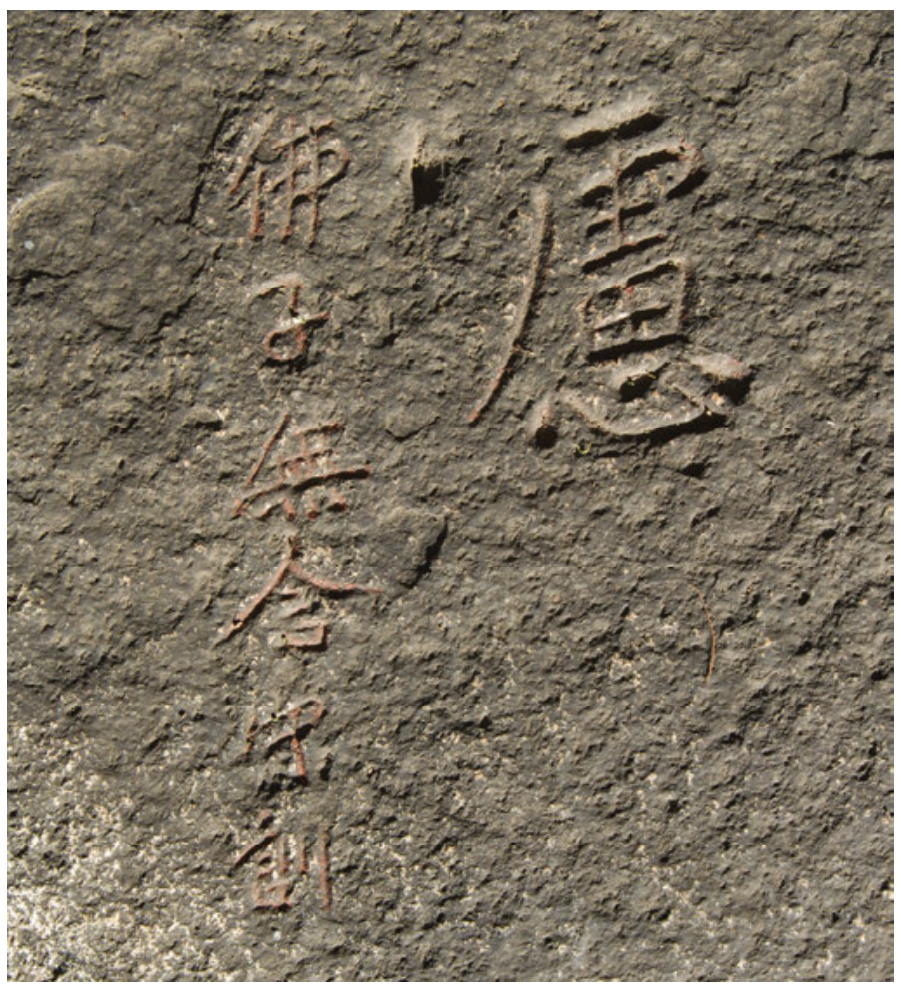

Fig. 3: Signature of Cheng Shouxun (detail of Fig. 2), Sūtra Stone Valley on Mount Tai. (c) Heidelberger Akademie der Wissenschaften.

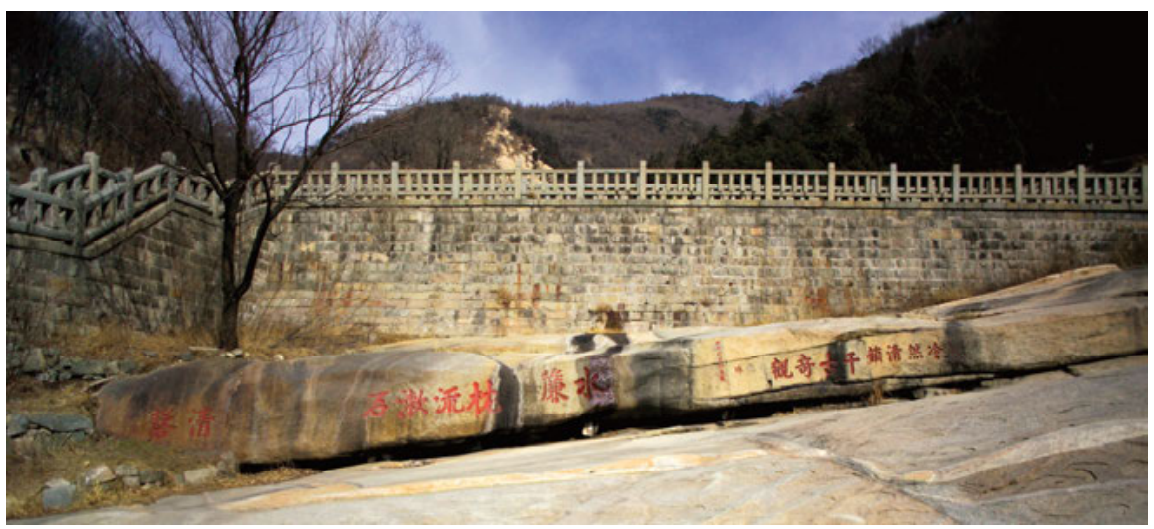

Fig. 4: Engraved epigraphs on the rock band north of the sūtra field, Sūtra Stone Valley on Mount Tai. @ Heidelberger Akademie der Wissenschaften. 


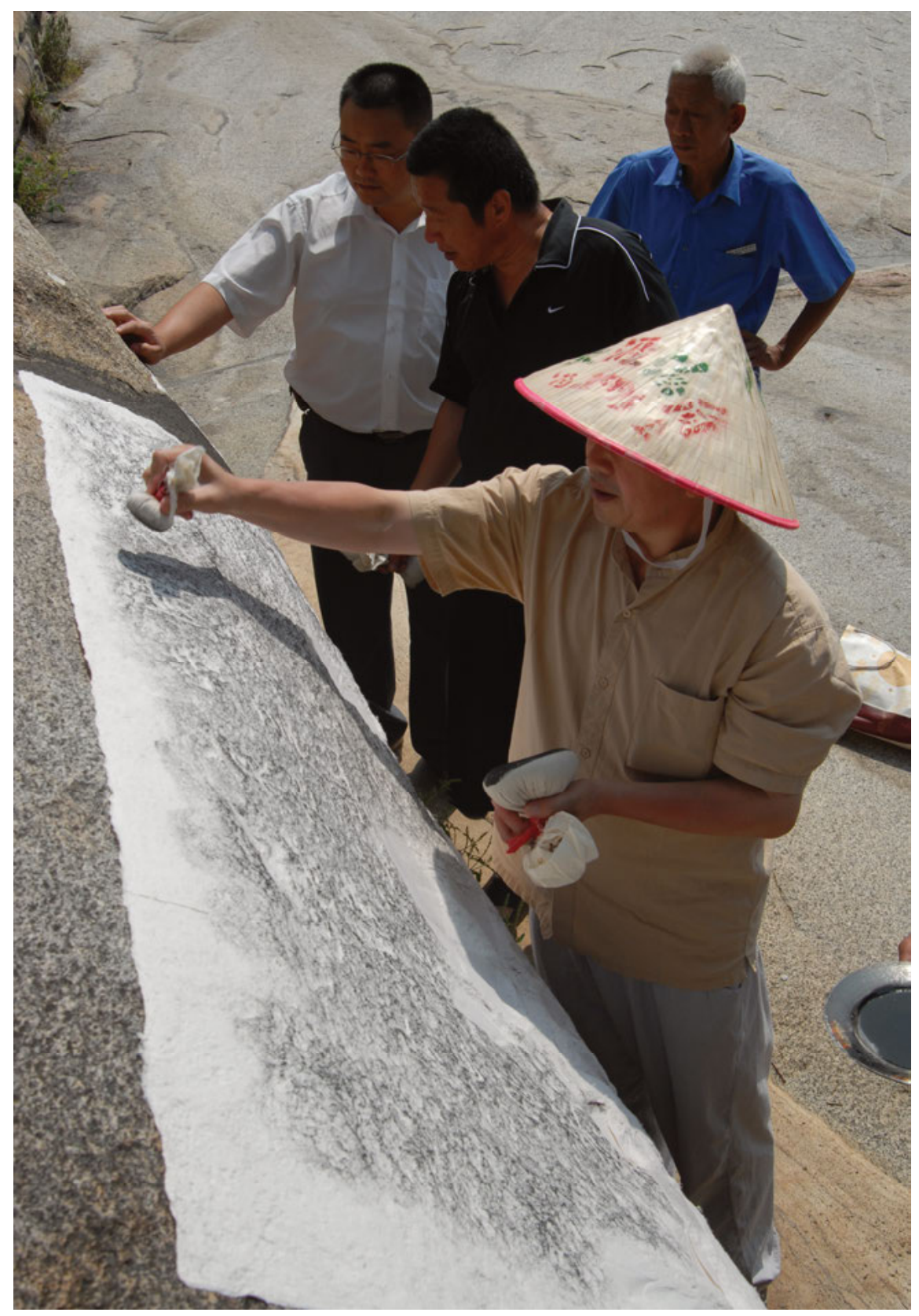

Fig. 5: Making a rubbing of the damaged poem by Cheng Shouxun in Sūtra Stone Valley on Mount Tai, 2015. () Heidelberger Akademie der Wissenschaften. 


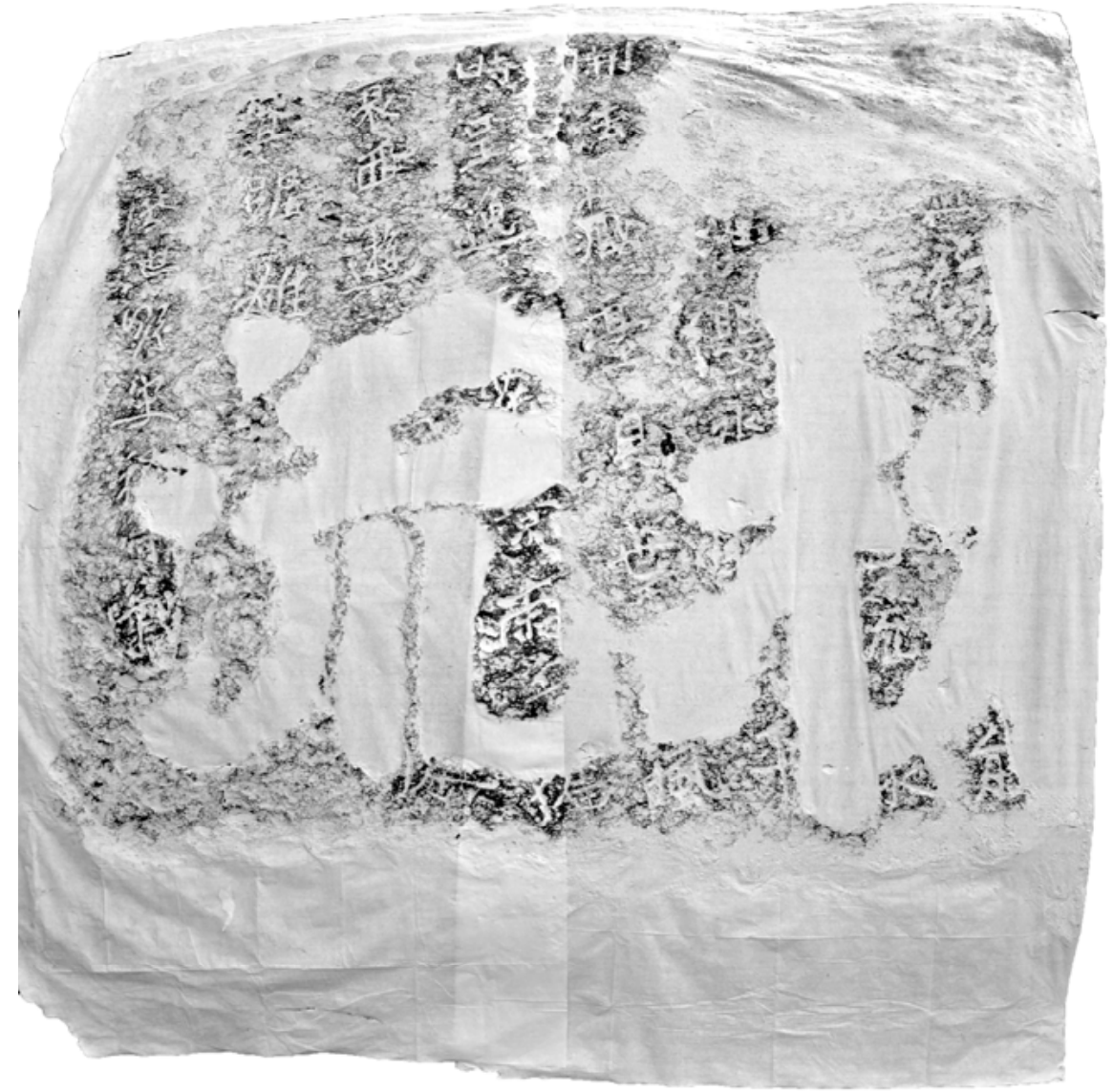

Fig. 6: Rubbing of the damaged poem by Cheng Shouxun, taken in 2015. ( $)$ Heidelberger Akademie der Wissenschaften. 


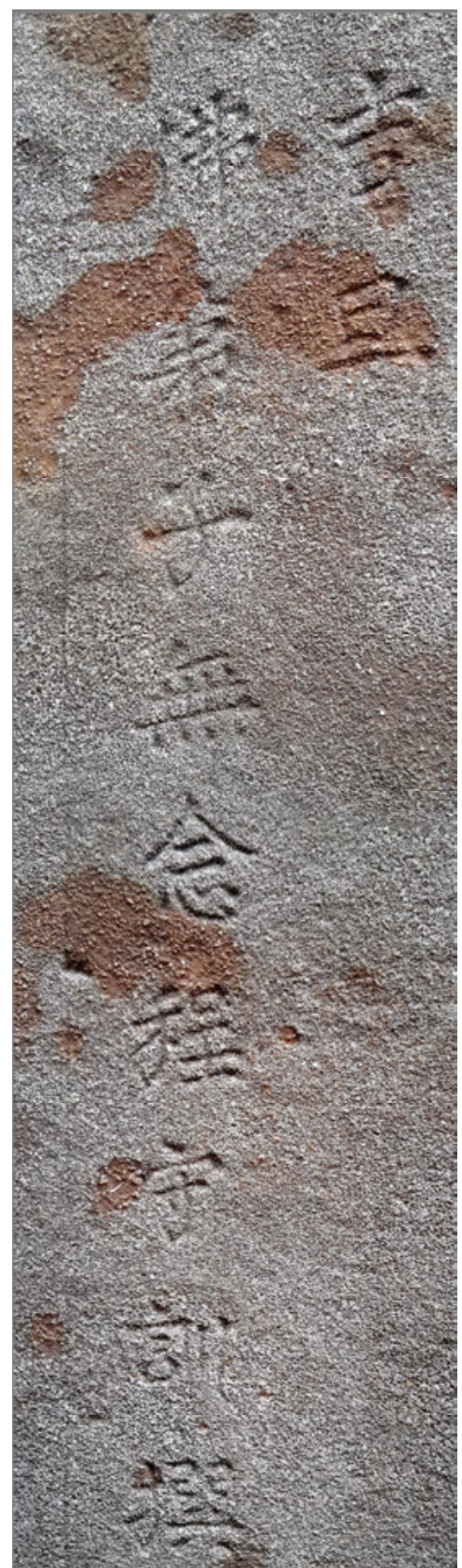

Fig. 7: Signature of Cheng Shouxun on a stele in the Daoist temple Sanyang Guan on Mount Tai, 1602. ( ) Heidelberger Akademie der Wissenschaften. 